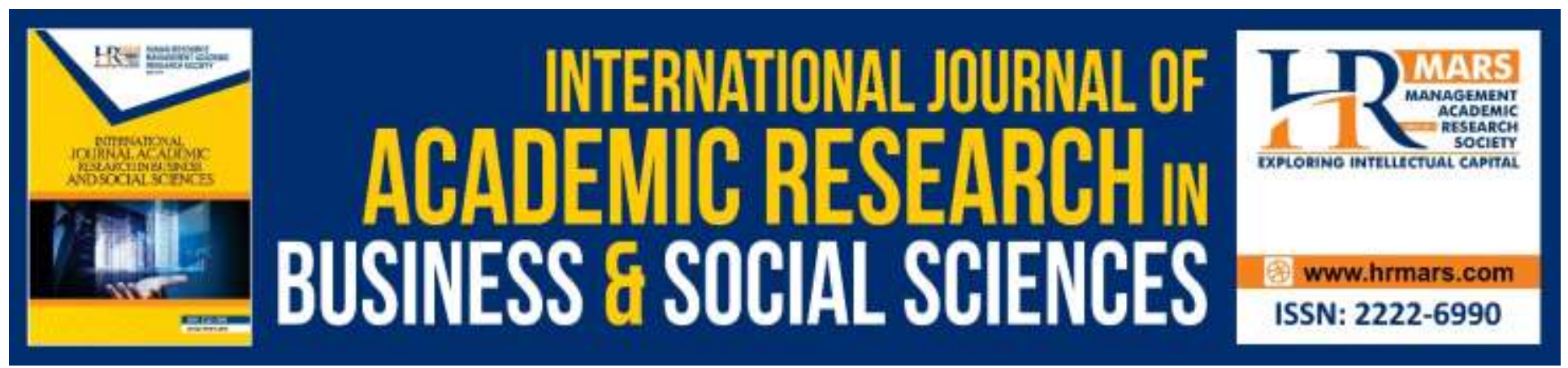

\title{
Parental Financial Socialisation: Pathways to Positive Financial Behaviour
}

\author{
Mohd Zamri Abu Bakar, Saridan Abu Bakar
}

To Link this Article: http://dx.doi.org/10.6007/IJARBSS/v10-i6/7260

DOI:10.6007/IJARBSS/v10-i6/7260

Received: 02 April 2020, Revised: 22 May 2020, Accepted: 29 May 2020

Published Online: 02 June 2020

In-Text Citation: (Bakar \& Bakar, 2020)

To Cite this Article: Bakar, M. Z. A., \& Bakar, S. A. (2020). Parental Financial Socialisation: Pathways to Positive Financial Behaviour. International Journal of Academic Research in Business and Social Sciences, 10(6), 5462.

Copyright: (C) 2020 The Author(s)

Published by Human Resource Management Academic Research Society (www.hrmars.com)

This article is published under the Creative Commons Attribution (CC BY 4.0) license. Anyone may reproduce, distribute, translate and create derivative works of this article (for both commercial and non-commercial purposes), subject to full attribution to the original publication and authors. The full terms of this license may be seen at: http://creativecommons.org/licences/by/4.0/legalcode

Vol. 10, No. 6, 2020, Pg. 54 - 62

Full Terms \& Conditions of access and use can be found at http://hrmars.com/index.php/pages/detail/publication-ethics 


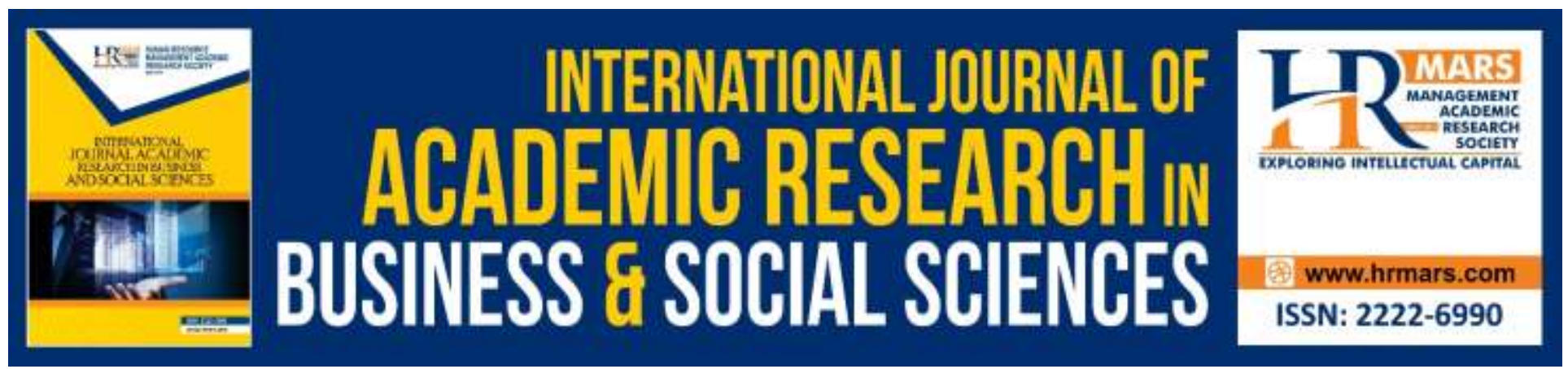

\title{
Parental Financial Socialisation: Pathways to Positive Financial Behaviour
}

\author{
Mohd Zamri Abu Bakara, Saridan Abu Bakarb \\ ${ }^{a}$ Faculty of Business Management, Universiti Teknologi Mara, Malaysia, ${ }^{\mathrm{b}}$ Arshad Ayub Business \\ School, Universiti Teknologi Mara, Malaysia
}

\begin{abstract}
This paper to seek discuss the importance and the roles of Parental Financial Socialisation (PFS) in today present life. This paper seeks to discuss the function of PFS in ensuring healthy financial behaviour and prudent financial practices. Further, this paper later expanded from concept and definitions of PFS to the benefits roles played by parents as financial socialisation agents. Significantly, PFS able to influence youth to be more financial literate, transform youth to change for more prudent financial management and provide them with competencies to manage their money management effectively.
\end{abstract}

Keywords: Parent, Socialisation, Knowledge, Behaviour, Youth.

\section{Introduction}

Research financial behaviour among youth has gained interest in recent economic situation. Living under one roof and the closet ones, parents has been identified as strong socialisation agents to exert influence on financial behavior and attitude of young age groups.

Parental financial socialisation (PFS) is considered as a lifelong process where individuals are constantly exposed to new financial patterns, experiences, social roles and situations throughout their lives by their parents (Basu \& Sondhi, 2014; Fu \& Padilla-Walker, 2019). The roles played by parents have significant impacts over the course of the lives of youth and allow them to engage and practice money management skills independently (Grohmann, 2018; Moschis, 1985). Literatures evidence has shown that the roles played by parents are not restricted only to the field of personal finance behaviour, but also applicable to other behaviour fields such as consumer socialisation, electricity consumption, education, psychology and eating behaviours (Aguirre-Bielschowsky, Lawson, Stephenson, \& Todd, 2018; Kim, Yang, \& Lee, 2015; Kraaykamp \& Notten, 2016; Vandewalle, Moens, Bosmans, \& Braet, 2017). Any financial information, knowledge gained and skills learned from parents either intentionally or unintentionally will benefit youth in terms of application of theoretical knowledge because it correlated with higher degrees of healthy financial behaviour and prudent financial practices. 
INTERNATIONAL JOURNAL OF ACADEMIC RESEARCH IN BUSINESS AND SOCIAL SCIENCES Vol. 10, No. 6, June, 2020, E-ISSN: 2222-6990 @ 2020 HRMARS

Although studies have revealed that youth learn and gain financial knowledge that shape their financial behaviour mainly from various socialisation agents such as parents, peers, media, formal education, religion, work experiences and internet, however, majority of the studies have clearly emphasised that parent are the most influential primary socialisation agent (Grohmann, 2018; Mikeska, Harrison, \& Carlson, 2017; Moreno-Herrero Salas-Velasco, \& Sánchez-Campillo, 2018). For an example, a study by Lyons, Scherpf, and Roberts (2006) found the majority (77\%) of youth depends on their parent for financial information compared with internet sources (33\%). Similarly, Shim Serido, Tang, and Card, (2015) in their longitudinal study among college students revealed that the impact parents have on youths' financial behaviours are stronger compared with formal education and informal learning or a combination of both agents. Kim, Yang, and Lee (2015) found that parents who shop with their children influence economic socialisation of their children. All these studies clearly pointed out that a strong relationship exists between parents and children. These statement findings further pointed that PFS plays significant roles and serves as dominant socialisation agent in developing youth to engage with healthy financial behaviour and prudent financial management compared to others socialisation agents. Thus, these indicate that PFS do significantly influence youths' financial practices, especially at the early stage of life and the learning process is likely to influence youth to manage their financial activities effectively in next stage of life. This paper attempt to discuss the importance roles of PFS and the relationship with healthy financial behaviours.

\section{Literature Review}

PFS can be defined as a development process where children establish financial values, attitude and behaviours that facilitate financial independence from their parents (Kagotho, Nabunya, Ssewamala, Mwangi, \& Njenga, 2017). Wu, Despard and Chowa (2017) referred to PFS as a process where children are exposed to money management and they establish their own financial behaviour, either incidentally or intentionally. It is a development stage where youth acquire and develop their own skills, perceptions and beliefs that influence them in the field of personal finance and money management matters. These characteristics are acquired from their parents and will be applied for the rest of their lives (Baumrind, 1980; Grohmann, 2018). According to Gudmunson and Danes (2011), PFS is associated with the development of financial attitude, financial capability and it is correlated to knowledge transfer. Shim, Barber, Card, Xiao, and Serido (2010) conceptualised PFS as financial learning and the development process gained from parents that influence the development of attitude and behaviour of children. It is a process of establishing financial attitude, standards, norms, knowledge and behaviours that enhances the financial well-being of an individual. In summary, PFS is defined as a development of socialisation process where the parents transfer knowledge and skills on financial matters either intentional or unintentionally that shape, develop skills, knowledge, attitude and financial practices of youth.

There are many ways how parents can socialise their children to be engaged in financial behaviour practices. According to Shim, Serido, Tang, and Card (2015), parental modelling, reinforcement, and strong communication are the effective ways to socialise children. Bucciol and Veronesi (2014) found that a combination of teaching methods by parents is the most dynamic financial learning method in shaping attitude and behaviours. Serido, Shim, Mishra, and Tang (2010) pointed out that explicit socialisation such as communication has been found to have more impact on developing financial behaviour compared with implicit socialisation such as role modelling, 
INTERNATIONAL JOURNAL OF ACADEMIC RESEARCH IN BUSINESS AND SOCIAL SCIENCES Vol. 10, No. 6, June, 2020, E-ISSN: 2222-6990 @ 2020 HRMARS

observation and imitation. Solheim, Zuiker, and Levchenko (2011) examined financial socialisation among university students and discovered that financial concepts such as saving, money management and family communication are mostly learned from their parents. Grohmann (2018) documented that parents' education background is the determining factor that determines the level of financial literacy among children. From the literature reviews, it seems reasonable to assume that there are various ways parents can socialise their children with financial development without realising the implications. This proves that PFS do significantly influence youths' financial practices, especially at the early stage of life and the learning process is likely to influence youth to manage their financial activities effectively.

Researchers have indicated that the type of parenting style and the way parents interact with their children influence children development (Kim et al., 2015; Mikeska et al., 2017). According to Baumrind (1980), parenting style can be defined as a way parents socialise their children and that parenting style can be categorised into three domains: authoritarian, permissive and authoritative. Zhu (2018) stressed that parenting style has an important influence on the economic orientation. Kordi and Baharudin (2010) found that authoritative parents have positive and significant influence on students' school achievement. Studies have shown that authoritative parenting styles have greater influence, effective and most preferred by parents compared with other parenting styles (Mikeska et al., 2017; Turner, Chandler, \& Robert, 2009). Similarly, financial socialisation by parents can lead to positive as well as negative youth behaviours (Solheim et al., 2011). Although, there are various types of parental styles, however, all the evidence comprehensively confirms that PFS is a key catalyst that influences youth's financial behaviour and further contributes to positive change in managing their own financial affairs. This suggest that PFS strongly contribute to present and future financial behaviours of youths.

Any financial habit or practice that is formed and established at early life age will have an influence throughout life of the individuals (Eccles, Templeton, Barber, \& Stone, 2003; Zhu, 2018). Achieving self-sufficiency is a critical developmental task during a period known as emerging adulthood, while achieving financial independence is one key marker of a successful transition to adulthood (Danziger \& Ratner, 2010). Perceived financial communication, perceived financial modelling, perceived parental financial expectation have been identified as effective ways for parents to socialise and develop positive financial behaviours (Shim et al., 2015). Families' financial activities such as opening a bank account, giving pocket money, conversation about savings and money issues, allowing children to observe money transactions influence youth in shaping and developing knowledge, skills and right attitude (Agnew, 2018). Evidence also shows that students develop a financial economic understanding, skills, and habits not just by talking with parents but also through their personal experiences, and learning by doing (Otto \& Webley, 2016). This proved that greater prevalence roles plays by parents in socialize their children and financial activities is considered as major force in educating children on money management effectively.

As individuals' habits are formed at early life age, parents able to exert huge of influence in development process of their children's financial habits and behaviours. Youth also develop their financial economic understanding, skills, and habits not just by talking with parents and observing their behaviours but also through their personal experiences and learning by doing financial activities 
together (Furnham, 1999; LeBaron, Hill, Rosa, \& Marks, 2018). By setting good examples, positive role models, norms and rules, all these processes create opportunities and allow children to experience managing financial affairs and participate in family financial activities actively with supervision from their parents. Danes and Yang (2014) pointed out that knowledge, norms and behaviour received by individual are correlated with positive financial practice. Parents who get their children actively involved in household financial activities through monitoring, communicating and implementing rules on financial activities may encourage their children to apply positive financial management in day today financial life activities. From the literature reviews, it seems reasonable to assume that there are various ways parents can socialise their children with financial development without realising the implications. This proves that PFS do significantly influence youths' financial practices, especially at the early stage of life and the learning process is likely to influence youth to manage their financial activities effectively.

\section{PFS Relationship with Positive Financial Behaviour}

PFS appears to have a great impact causing many behavioural changes among youth. Numerous studies have found evidence on the existence of a relationship on the role played by parents and economic knowledge, behaviour and attitude of children, adolescents and adults (Fu \& Padilla-Walker, 2019; McNeil \& Turner, 2013; Sabri, Cook, \& Gudmunson, 2012). It all started from the house where the children live, under one roof and are socialised with managing money by their parents. Shim et al., (2015) pointed out that perceived PFS has strong relationship with financial attitude, financial controllability and financial efficacy. Parents who are active in socialising and influencing good financial behaviour and practices will encourage their children to practise higher degree of financial literacy (Grohmann, 2018). Additionally, literatures has shown that parent-youth relationship and its impact can be proven in many aspects of youth life, such as increased knowledge, financial planning, saving, economic orientation, household wealth, asset ownership and economic socialisation (Bucciol \& Veronesi, 2014; Hira, Sabri, \& Loibl, 2013; Kim, Yang, \& Lee, 2015; Otto \& Webley, 2016). These evidence clearly indicates that PFS is able to develop youths' competencies, subsequently encouraging youth to behave prudently and practising positive financial behaviour in their daily financial life.

Since youth are in the transitional stage from teenager to adulthood, any financial practices and repetitive exposures can benefit them to become more independent in making decisions, experiencing money management and in managing their own financial resources effectively (Moreno-Herrero et al., 2018; Te'eni-Harari, 2016). McNeil and Turner (2013) stressed that the relationship is very strong, specifically within the area of financial habits and financial decisionmaking skills. Parents can shape attitudes towards money by demonstrating positive financial behaviour, while living together at home (LeBaron et al., 2018). Any financial practices or habits acquired and derived from parents during the transition from adolescence to adulthood will be imitated and be further continued in their next stage in life. Parents who provide hands-on experience in matters such as how to manage a bank account, financial planning and provide supervision during childhood have been acknowledged as the best attributes of youth economic wellbeing (Sinha, Tan, \& Zhan, 2018). They have been proven as effective tools in developing youth financial skills and have been associated with asset ownership when they grow and become adults. Financial knowledge, skills and attitudes acquired or transmitted from parents, specifically through 
INTERNATIONAL JOURNAL OF ACADEMIC RESEARCH IN BUSINESS AND SOCIAL SCIENCES Vol. 10, No. 6, June, 2020, E-ISSN: 2222-6990 @ 2020 HRMARS

informal channels such as communication, observation, approved decision, discussion and guidance are considered ultimate influence towards youths' financial behaviour.

Numerous literatures in socialisation emphasised that parental socialisation influences saving behaviour and increases household wealth (Kagotho et al., 2017; Webley \& Nyhus, 2013; Wu et al., 2017). For example, Kagotho et al., (2017) found that parental socialisation influences saving behaviour among youth following their family's spending patterns, saving plans and parents who persuade their children to engage in family financial decisions exhibit higher saving behaviour. Saving can also be learned through observation of parents' saving behaviour, conversations on saving and family saving rules (Solheim, Zuiker, \& Levchenko, 2011). A combination of teaching methods such as giving pocket money, monitoring use of money and parents providing financial advice to their children at a young age will instil significant intentions and amount of money to save when the children grow up and become adults (Bucciol \& Veronesi, 2014). Te'eni-Harari (2017) documented that perceived influence played by parents and peer attitudes have strong influence on intention to save money. Financial habits learned through modelling and intentional teaching from parents are correlated with financial proficiency. Considering that the young age group mirrors their parents' practices and behaviour, undoubtedly, parents can shape and encourage them to adopt positive financial behaviour by providing them with equal practical opportunities.

The early introduction of money management by parents is linked with positive financial outcomes in adulthood (Isomidinova \& Singh, 2017; Grinstein-Weiss, Spader, Yeo, Taylor, \& Freeze, 2011). While doing activities such as shopping, the mother and father can socialise youth on consumption experiences by allowing them to observe, experience money transactions and enabling them to gain experience in financial independence such as knowledge on how to shop and what to buy (Minahan \& Huddleston, 2010). As parents are close to them and youth live under the same roof with parents, therefore parents can become the primary source of financial information and become the financial role model to the younger family members. For example, Grinstein-Weiss et al., (2011) discovered that when parents expose their young family members to money management, youth will most likely experience lower credit card debts and higher credit scores. On the other hand, Bucciol and Veronesi (2014) discovered that individuals who did not receive any parental guidance during their early age, will take longer to save compared with those who have received early exposure from their parents. The more parents talk about money matters with their children, the more knowledgeable will their children feel about personal finance as youth.

Financial independence has been acknowledged as a major milestone during the transition stage to emerging adulthood (Arnett, 2000). Webely and Nyhus (2013) conducted a study among young adults in the Netherlands and discovered that parents who teach their children on budgeting and inculcate the habit of saving in them will make young age group able to control their spending expenditures, prefer to save rather than to spend, future oriented in financial matters and have higher tendency to save more. By observing their parents' financial activities, getting involved in family financial practices and joining them in making household financial decisions, youth will gain valuable knowledge and experience in managing financial affairs (Sinha et al., 2018).Through parental monitoring, youth are given the opportunity to apply their financial skills, and have better understanding on financial transactions and money management. The study by Norvilitis and 
INTERNATIONAL JOURNAL OF ACADEMIC RESEARCH IN BUSINESS AND SOCIAL SCIENCES Vol. 10, No. 6, June, 2020, E-ISSN: 2222-6990 @ 2020 HRMARS

MacLean (2010) revealed that parental facilitation has a strong positive effect on credit card debt and decrease in the use of credit cards among students. Thus, from the finding, parental socialisation can be summarised as important tool that can prevent youth from falling into financial problems. As the most influential socialisation agent, parents who practise positive financial practices, can help narrow the gap in financial knowledge to benefit youth to become competent financial manager.

\section{Conclusion}

Parents as primary socialisation agent can foster financial behaviour and can facilitate financial activities of youth by being good financial role models in managing their money. Any financial information received from parents either intentionally or unintentionally positively and significantly increases financial knowledge and financial practices of youth. Children or youth living under the same roof, with the parents cultivating financial socialisation shave shown that they have better financial practices. The financial practices or behaviours by parent will be observed, followed and will be imitated in their daily financial life. Based on the evidence in the literature, it is clear that parents are able to exert positive influence in shaping behaviour, boost confidence level and determine attitude for youth towards practising prudent financial management. Active parental socialisation is a positive predictor to better financial decisions in adulthood. The roles played by parents regarding financial activities and indirect teaching, influence the financial outcomes of youth and are positively significant to healthy financial behaviour and to positive financial practices. It seems reasonable that during emerging adulthood, parents will serve as primary financial socializing agents in relevant domain of financial activities. It is recommended that the future studies can access how parental financial socialisation affect youth life across transition age groups and compare the variance of changes on behaviours of youth.

\section{References}

Agnew, S. (2018). Empirical measurement of the financial socialisation of children by parents. Young Consumers. doi:10.1108/yc-07-2017-00717

Aguirre-Bielschowsky, I., Lawson, R., Stephenson, J., \& Todd, S. (2018). Kids and kilowatts: Socialization, energy efficiency, and electricity consumption in New Zealand. Energy Research \& Social Science, 44, 178-186.

Arnett, J. J. (2014). Emerging adulthood. Oxford University Press, Second Edition.

Basu, R., \& Sondhi, N. (2014). Child socialization practices: Implications for retailers in emerging markets. Journal Retail Consumer Service, 21(5), 797-803.

Baumrind, D. (1980). New direction in socialization research. American Psychologist, 35(7), 639-652.

Bucciol, A., \& Veronesi, M. (2014). Teaching children to save and lifetime saving: What is the best strategy?. Journal of Economic Psychology, 45, 1-17.

Danes, S. M., \& Yang, Y. (2014). Assessment of the use of the theories within the journal of the financial counseling and planning and the contribution of the family financial socialization conceptual model. Journal of Financial Counseling and Planning, 25(1), 53-68.

Danziger, S., \& Ratner, D. (2010). Labor market outcomes and transition to adulthood. The future children, 20, 133-158.

Eccles, D. W., Ward, P., Goldsmith, E., \& Arsal, G. (2013).The relationship between retirement wealth and householders' lifetime personal finance and investing behaviors. Journal of Consumer Affairs, 47(3), 432-464. 
INTERNATIONAL JOURNAL OF ACADEMIC RESEARCH IN BUSINESS AND SOCIAL SCIENCES

Vol. 10, No. 6, June, 2020, E-ISSN: 2222-6990 @ 2020 HRMARS

Falahati, L., \& Paim, L. (2012). Experiencing financial problems among university students. Gender in Management, 27(5), 315-330.

Fu, X., \& Padilla-Walker, L. M. (2019). It's much more than money! Relations between adolescents' financial entitlement and behavioral outcomes. The Journal of Early Adolescence, 39(1), 28-40.

Furnham, A. (1999). Personality and creativity. Perceptual and Motor Skills, 88(2), 407-408.

Grinstein-Weiss, M., Spader, J., Yeo, Y. H., Taylor, A., \& Freeze, E. B. (2011). Parental transfer of financial knowledge and later credit outcomes among low-and moderate- income home owners. Children and Youth Services Review, 33, 78-85.

Grohmann, A. (2018). Financial literacy and financial behavior: Evidence from the emerging Asian middle class. Pacific-Basin Finance Journal, 48, 129-143.

Gudmunson, C. G., \& Danes, S. M. (2011). Family financial socialization: Theory and critical review. Journal of Family and Economic Issues, 32(4), 644-667.

Hira, T. K., Sabri, M. F., \& Loibl, C. (2013). Financial socialization's impact on investment orientation household and net worth. International Journal of Consumer Studies, 37, 29-35.

Isomidinova, G., \& Singh, J. S. K. (2017). Determinants of financial literacy: A quantitative study among young students in Tashkent, Uzbekistan. Electronic Journal of Business \& Management, 2(1), 61-75.

Kagotho, N., Nabunya, P., Ssewamala, F., Mwangi, E. N., \& Njenga, G. (2017). The role of family financial socialization and management skills on youth saving behavior. Journal of Adolescence, 57,134-138.

Kim, C., Yang, Z., \& Lee, H. (2015). Parental style, parental practice and socialization outcomes: An investigation of their linkages in the consumer socialization context. Journal of Economic Psychology, 49, 15-23.

Kordi, A., \& Baharudin, R. (2010). Parenting attitude style and its effect on children school achievements. International Journal of Psychological Studies, 2(2), 217-222.

Kraaykamp, G., \& Notten, N. (2016). Parental cultural socialization and educational attainment. Trend effects of traditional cultural capital and media involvement. Research on social stratification and mobility, 45, 63-71.

Kuczynski, L., Parking, C. M., \& Pitman, R. (2015). Socialization as dynamic process: A dialectical, transactional perspective. In J. E. Grusec, \& P. D. Hastings (Eds.). Handbook of Socialization: Theory and Research (pp. 135-157). New York: Guilford Press.

LeBaron, A. B., Hill, E. J., Rosa, C. M., \& Marks, L. D. (2018). What's and how's of family financial socialization: Retrospective reports of emerging adults, parents, and grandparents. Family Relations, 67(4), 497-509.

Lyons, A. C., Scherpf, E. M., \& Robert. H. (2006). Financial education and communication between parents and children. The Journal of Consumer Education, 23, 64-67.

McNeil, L. S., \& Turner, L. (2013). Parental financial role modeling and fiscal behavior of young home leavers. Young Consumers, 14, 122-138.

Mikeska, J., Harrison, L. R., \& Carlson, L. (2017). A meta-analysis of parental style and consumer socialization of children. Journal of Consumer Psychology, 27 (2), 245-256.

Minahan, S., \& Huddleston, P. (2010).Shopping with mum - mother and daughter consumer socialization. Youth Consumers: Insight and Ideas for Responsible Marketers, 11 (3), 170-177.

Moreno-Herrero, D., Salas-Velasco, M., \& Sánchez-Campillo, J. (2018).The knowledge and 
INTERNATIONAL JOURNAL OF ACADEMIC RESEARCH IN BUSINESS AND SOCIAL SCIENCES

Vol. 10, No. 6, June, 2020, E-ISSN: 2222-6990 @ 2020 HRMARS

skills that are essential to make financial decisions: First results from PISA 2012. Finance Archive: Public Finance Analysis, 74 (3), 293-334.

Moschis, G. P. (1985). The role of family communication in consumer socialization of children and adolescents. Journal of Consumer Research, 11(4), 898-913.

Norvilitis, J. M., \& Mao, Y. (2013). Attitudes toward credit and finance among college students in China and the United States. International Journal of Psychology, 48 (3), 389-398.

Norvilitis, J. M., \& Maclean, M. G. (2010). The role of parents in college student's financial behaviors and attitudes. Journal of Economic Psychology, 31, 55-63.

Nyhus, E. K., \& Webley, P. (2013). The relationship between parenting and the economic behaviour and orientation of Norwegian Adolescents. Journal of Genetic Psychology, 176, 620-641.

Otto, A., \& Webley, P. (2016). Saving, selling, earning, and negotiating: How adolescents acquire monetary lump sums and who considers saving. Journal of Consumer Affairs, 50 (2), 342-371

Sabri, M. F., Cook, C. C., \& Gudmunson, C. G. (2012). Financial well-being of Malaysian college students. Asian Education and Development Studies, 1(2), 153-170.

Serido, J., Shim, S., Mishra, A., \& Tang, C. C. (2010). Financial parenting, financial coping behaviors, and well-being of emerging. Adults. Family Relations, 59 (4), 453-464.

Shim, S., Serido, J., Tang, C., \& Card, N. (2015). Socialization process and pathways to healthy financial development. Journal of Applied Development Psychology, 38, 29-38.

Shim, S., Barber, B., Card, N., Xiao, J. J., \& Serido, J. (2010). Financial socialization of Young adults: The role of family, work, and education. Journal of Youth and Adolescence, 39, 1457-1470.

Sinha, G., Tan, K., \& Zhan, M. (2018). Patterns of financial attributes and behaviors of emerging adults in the United States. Children and Youth Services Review, 93, 178-185. doi:10.1016/j.childyouth.2018.07.023.

Solheim, C. A., Zuiker, V. S., \& Levchenko. P. (2011). Financial socialization of family pathways: Reflection from college student's narratives. Family Science Review. 16, 97-112

Te'eni-Harari, T. (2016). Financial literacy among children. The role of involvement in saving money. Young consumer, 2, 197-208.

Turner, E. A., Chandler, M., \& Robert, R. W. (2009). The influence of parenting styles, achievement, motivation and self efficacy on academic performance in college student. Journal of College Development, 50 (3), 337-346.

Vandewalle, J., Moens, E. Bosmons, G., \& Braet, C. (2017). The effect of parental rejection on the emotional eating behavior of youngsters: A laboratory-based study. Appetite, 108, 219-225.

Webley, P., \& Nyhus, E. K. (2013) Economic socialization, saving and assets in European young adults. Economics of Education Review, 33, 19-30

Wu, S., Despard, M. R., \& Chowa, G. (2017). The role of parents in introducing children to financial services: Evidence from Ghana-YouthSave. Journal of Family and Economic Issues, 38(3), 453462.

Xiao, J., Tang, C., Serido, J., \& Shim, S. (2011). Antecedents and consequences of risky credit behavior among college students: Application and extension of the theory of planned behavior. Journal of Public Policy and Marketing, 30(2), 239-245.

Zhu, A. Y. F. (2018). Links between family poverty and the financial behaviors of adolescents: Parental roles. Child Indicators Research.doi.org/10.1007/ s12187-018-9588-6. 